\title{
ANALISIS FAKTOR PENGHAMBAT UMKM DI KECAMATAN CILEUNGSI
}

\author{
Awang Surya \\ Sekolah Tinggi Teknologi Muhammadiyah Cileungsi, awang_surya@yahoo.com
}

\begin{abstract}
ABSTRAK
Data-data resmi membuktikan begitu besarnya peran UMKM terhadap perekonomian Indonesia. Tetapi fakta di lapangan menunjukkan bahwa bisnis UMKM tidak selalu berjalan mulus, masih banyak hambatan dan kendala, baik yang bersifat internal maupun eksternal. Tidak sedikit UMKM yang tidak bisa berkembang dengan baik dan akhirnya gulung tikar. Geliat ekonomi di wilayah Kecamatan Cileungsi tampak meningkat terlihat UMKM tumbuh seiring dengan bertambahnya jumlah warga. Semua pihak perlu mendukung tumbuh kembangnya UMKM di wilayah Kecamatan Cileungsi agar bisa memberi dampak yang baik bagi masyarakat. Penelitian yang dilakukan bertujuan untuk mendapat gambaran profil UMKM di wilayah Kecamatan Cileungsi dan hambatan yang dihadapi di dalam mengembangkan usaha. Metode yang dilakukan adalah penelitian deskriptif dengan survey menggunakan instrumen angket. Hasil yang didapat dari penelitian ini dengan sampel sebanyak 63 responden, diketahui bahwa komposisi UMKM di Kecamatan Cileungsi adalah mayoritas adalah usaha mikro. Berdasarkan jenis usahanya diketahui bahwa jenis usaha yang paling diminati adalah kuliner. Bidang-bidang lain jumlahnya hampir seimbang yaitu konveksi, kerajinan tangan dan perdagangan. Hambatan terbesar yang dihadapi UMKM Kecamatan Cileungsi adalah bidang pemasaran dan keuangan.
\end{abstract}

Kata Kunci: UMKM, hambatan usaha

\begin{abstract}
Official data prove the role of MSMEs in the Indonesian economy. However, the facts in the field show that the MSME business does not always run smoothly, there are still many obstacles and obstacles, both internal and external. Not a few MSMEs cannot develop properly and eventually go out of business. The economic activity in the area of Cileungsi District seems to be increasing, it can be seen that MSMEs are growing along with the increase in the number of residents. All parties need to support the growth and development of MSMEs in the area of Cileungsi District so that they can have a good impact on the community. This research aims to get an overview of the profile of MSMEs in the Cileungsi District and the obstacles faced in developing a business. The method used is descriptive research with a survey using a questionnaire instrument. The results obtained from this study with a sample of 63 respondents, it is known that the composition of MSMEs in Cileungsi District is the majority are micro enterprises. Based on the type of business, it is known that the type of business that is most in demand is culinary. Other fields are almost equal in number, namely convection, handicrafts and trade. The biggest obstacles faced by MSMEs in Cileungsi District are marketing and finance.
\end{abstract}

Keywords: MSMEs, business barriers

Naskah diterima : 24-06-2021, Naskah dipublikasikan : 28-09-2021 


\section{PENDAHULUAN}

Usaha Mikro, Kecil dan Menengah (UMKM) merupakan kelompok usaha yang perannya sangat signifikan dalam perekonomian Indonesia (Hartono \& Hartomo, 2016). Dalam beberapa tahun terakhir, kontribusi sektor usaha mikro, kecil, dan menengah terhadap produk domestik bruto meningkat. Statistik menunjukkan dalam lima tahun terakhir terjadi kontribusi sektor UMKM meningkat dari 57,84 persen menjadi 60,34 persen. Serapan tenaga kerja pada sektor ini juga meningkat, dari 96,99 persen menjadi 97,22 persen pada periode yang sama (Kemenperin, 2016). Secara kuantitas pelaku UMKM juga sangat besar yaitu 99,99\% dari total keseluruhan pelaku usaha di Indonesia atau sebanyak 56,54 juta unit (Suci et al., 2017).

Dari beberapa kali krisis ekonomi yang telah terjadi terlihat dampak buruk kondisi ekonomi di Indonesia. Di masa krisis banyak perusahaan besar yang gulung tikar dan sehingga terjadi pemutusan hubungan kerja yang luar biasa seperti yang terjadi di tahun 1998 (Rahmadi et al., 2018). Tetapi dari beberapa krisis yang telah terjadi terlihat sektor UMKM (Usaha Mikro Kecil dan Menengah) mampu tetap berdiri kokoh. UMKM yang selama ini kurang mendapatkan perhatian ternyata justru mampu bertahan di tengah badai krisis ekonomi dan mampu menggerakkan roda perekonomian dengan kekuatan sendiri (Sarfiah et al., 2019). Data Badan Pusat Statistik menunjukkan fakta bahwa pasca krisis ekonomi jumlah UMKM tidak berkurang, justru meningkat. Bahkan sektor UMKM mampu menyerap 85 juta hingga 107 juta tenaga kerja sampai tahun 2012. Pada tahun itu jumlah pengusaha di Indonesia sebanyak 56.539.560 unit (Suci et al., 2017).

Fenomena ini menjelaskan bahwa UMKM merupakan sektor usaha yang layak untuk dikembangkan bagi mendukung perkembangan ekonomi secara makro dan mikro Indonesia. Perkembangan sektor UMKM diharapkan akan mempengaruhi sektor-sektor yang lain. Dewan Ekonomi Nasional (DEN) merekomendasikan tujuan pembangunan Indonesia di masa datang untuk meningkatkan kesejahteraan masyarakat Indonesia dengan menyusun strategi jangka menengah, antara lain menetapkan kebijakan pengentasan kemiskinan dengan cara memelihara kestabilan ekonomi dan membuka lapangan kerja melalui pengambangan UMKM.(Lenora, 2008). Data-data resmi telah membuktikan begitu besarnya peran UMKM terhadap perekonomian Indonesia. Tetapi fakta di lapangan menunjukkan bahwa bisnis UMKM tidak selalu berjalan mulus, masih banyak hambatan dan kendala, baik yang bersifat internal maupun eksternal yang harus dihadapi para pelaku UMKM (Bank Indonesia dan LPPI, 2015). Tidak sedikit UMKM yang tidak bisa berkembang dengan baik. Beberapa fakta menunjukkan bahwa kinerja UKM di Indonesia masih relatif buruk, bukan saja dibanding dengan usaha besar tetapi juga dibandingkan dengan UKM di negara-negara maju (Sabirin, 2016).

Kecamatan Cileungsi adalah salah satu kecamatan yang ada di wilayah Kabupaten Bogor. Posisi geografis Kecamatan Cileungsi yang dekat dengan Provinsi DKI Jakarta membuatnya perkembangan wilayah ini sangat pesat. Geliat ekonomi di wilayah ini juga tampak meningkat. UMKM tumbuh seiring dengan bertambahnya jumlah warga. Semua pihak perlu mendukung tumbuh kembangnya UMKM di wilayah Kecamatan Cileungsi agar bisa memberi dampak yang baik bagi masyarakat. Selama ini belum ada penelitian yang mengungkap hambatan yang dihadapi para pelaku UMKM di Kecamatan Cileungsi. Memperhatikan fakta di atas maka penting untuk diadakan penelitian yang bertujuan untuk mengetahui profil para pelaku UMKM di wilayah Kecamatan Cileungsi dan hambatan yang dihadapi dalam mengembangkan usaha. Dalam hal ini studi kasus difokuskan pada UMKM yang tergabung dalam organisasi Forum UMKM Cileungsi. Hasil dari penelitian ini diharapkan dapat menjadi dasar bagi para pengambil kebijakan untuk menentukan langkah di dalam membantu UMKM di Kecamatan Cileungsi. Hal tersebut diharapkan bisa meningkatkan ekonomi masyarakat secara umum. 


\section{KAJIAN LITERATUR \\ Pengertian UMKM}

Pengertian lengkap mengenai UMKM dapat ditemukan di dalam Undang-Undang Republik Indonesia Nomor 20 Tahun 2008 Tentang Usaha Mikro, Kecil dan Menengah.(Jamkrindo, 2015) Dalam undang-undang tersebut UMKM dijelaskan sebagai: "Sebuah perusahaan yang digolongkan sebagai UMKM adalah perusahaan kecil yang dimiliki dan dikelola oleh seseorang atau dimiliki oleh sekelompok kecil orang dengan jumlah kekayaan dan pendapatan tertentu." (Bank Indonesia dan LPPI, 2015)

Secara sederhana kriteria UMKM dan usaha besar dapat dilihat dari tabel berikut ini:

Tabel 1. Kriteria UMKM Usaha Besar Berdasarkan Aset dan Omset

\begin{tabular}{|l|l|l|}
\hline \multirow{2}{*}{ UKURAN USAHA } & \multicolumn{2}{|c|}{ KRITERIA } \\
\cline { 2 - 3 } & \multicolumn{1}{|c|}{ ASET } & \multicolumn{1}{c|}{ OMSET } \\
\hline Usaha Mikro & Maksimal Rp 50 juta & Maksimal Rp 300 juta \\
\hline Usaha Kecil & $>$ Rp50 juta - Rp500 juta & $>$ Rp300 juta - Rp2,5 miliar \\
\hline Usaha Menengah & $>$ Rp500 juta - Rp10 miliar & $>$ Rp2,5 miliar- Rp50 miliar \\
\hline Usaha Besar & $>$ Rp10 miliar & $>$ Rp50 miliar \\
\hline
\end{tabular}

\section{Karakteristik UMKM}

Secara umum UMKM juga memiliki karakteristik tersendiri antara lain: (Bank Indonesia dan LPPI, 2015)

a. Kualitasnya belum standar. Karena sebagian besar UMKM belum memiliki kemampuan teknologi yang memadai. Produk yang dihasilkan biasanya dalam bentuk handmade sehingga standar kualitasnya beragam.

b. Desain produknya terbatas. Hal ini dipicu keterbatasan pengetahuan dan pengalaman mengenai produk. Mayoritas UMKM bekerja berdasarkan pesanan, belum banyak yang berani mencoba berkreasi desain baru.

c. Jenis produknya terbatas. Biasanya UMKM hanya memproduksi beberapa jenis produk saja. Apabila ada permintaan model baru, UMKM sulit untuk memenuhinya. Kalaupun menerima, membutuhkan waktu yang lama.

d. Kapasitas dan daftar harga produknya terbatas. Dengan kesulitan menentukan kapasitas produk dan harga membuat konsumen kesulitan.

e. Bahan baku kurang terstandar. Karena bahan bakunya diperoleh dari berbagai sumber yang berbeda.

f. Kontinuitas produk tidak terjamin dan kurang sempurna. Karena produksi belum teratur maka biasanya produk-produk yang dihasilkan sering apa adanya.

Dari penelitian yang telah dilakukan peneliti sebelumnya didapatkan fakta bahwa UMKM banyak menghadapi kendala. Hambatan itu bisa dari faktor internal dan eksternal. Dari sisi internal hambatannya adalah modal yang terbatas, SDM yang terbatas kualitasnya, dan lemahnya jaringan pasar. Sementara dari sisi eksternal adalah diantaranya iklim usaha yang kurang kondusif bagi UMKM, terbatasnya sarana dan prasarana, beberapa peraturan dan perundang-undangan yang tidak berpihak kepada UMKM (Adawiyah, 2014). Dari penelitian lain ditemukan bahwa kendala perkembangan UMKM ada beberapa faktor baik internal maupun eksternal. Beberapa faktor tersebut antara lain keterbatasan modal usaha, keterbatasan sumber daya manusia (SDM) dan keterbatasan teknologi (Hasanah et al., 2020). Qomariah Lahamid (2018) menyampaikan beberapa masalah yang dihadapi UKM promosi dan pemasaran, pengelolaan (manajerial), teknologi informasi, desain serta jejaring (networking) serta masalah pembiayaan 


\section{METODE PENELITIAN}

Jenis Penelitian

Menurut tujuannya penelitian yang akan dilakukan ini adalah penelitian deskriptif yaitu metode penelitian yang ditujukan untuk menggambarkan fenomena-fenomena yang ada, yang berlangsung pada saat ini atau saat yang lampau (Moh. Nazir, 2014). Teknik pengumpulan data yang digunakan adalah survey dengan instrumen angket.

\section{Tujuan Operasional Penelitian}

1. Untuk mengetahui klasifikasi dan jenis usaha UMKM di Kecamatan Cileungsi

2. Untuk mendapatkan informasi faktor-faktor yang menjadi hambatan UMKM di Kecamatan Cileungsi

\section{Tempat dan Waktu Penelitian}

Penelitian dilakukan Kecamatan Cileungsi, Kabupaten Bogor, Provinsi Jawa Barat. Waktu penelitian adalah bulan Januari sampai Februari tahun 2021

\section{Populasi}

Dalam penelitian ini anggota populasi yang akan diteliti adalah pelaku usaha yang tergabung di dalam Forum UMKM Cileungsi, Kecamatan Cileungsi, Kabupaten Bogor, Provinsi Jawa Barat.

\section{Teknik Pengumpulan Data}

1. Tahap persiapan

Penyusunan Instrumen penelitian (angket):

1. Penyusunan rancangan angket

2. Uji coba angket

3. Revisi Angket

4. Penggandaan Angket

2. Tahapan Pelaksanaan
a. Pengumpulan data

b. Dokumentasi

\section{Diagram Alir}

Urutan kegiatan penelitian ini tergambar di dalam diagram alir di bawah ini. 


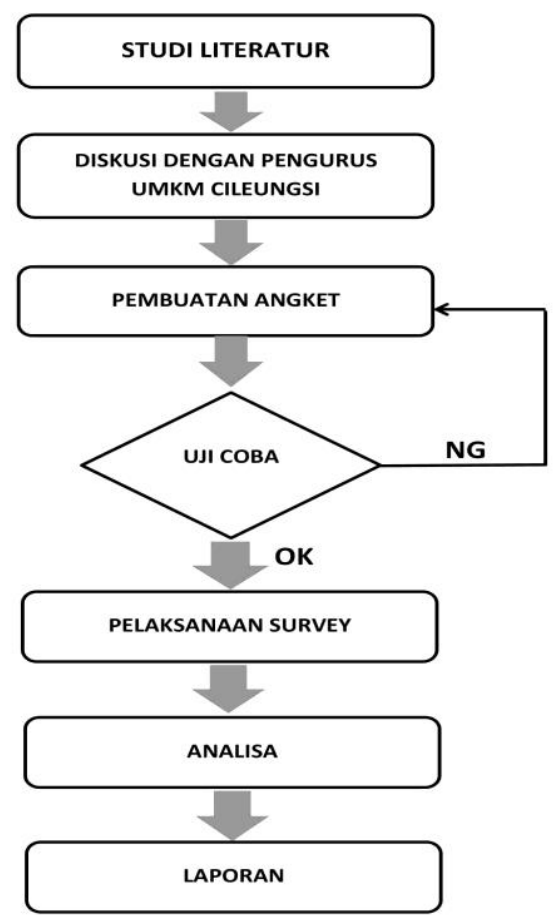

Gambar 1. Diagram Alir Penelitian

\section{HASIL PENELITIAN DAN PEMBAHASAN}

Kecamatan Cileungsi adalah salah satu dari 40 kecamatan yang ada di wilayah Kabupaten Bogor. Data dari laman resmi Badan Pusat Statistik (BPS) Kabupaten Bogor https://bogorkab.bps.go.id/ didapatkan bahwa Kecamatan Cileungsi adalah kecamatan dengan jumlah penduduk terbanyak ketiga, setelah Kecamatan Gunungputri dan Kecamatan Cibinong. Dengan jarak kurang lebih $30 \mathrm{Km}$ dari ibu kota Negara Jakarta, Kecamatan Cileungsi telah tumbuh menjadi wilayah penyangga ibu kota. Informasi resmi dari laman http://blh.bogorkab.go.id/ menyebutkan bahwa ada 4 kecamatan di Kabupaten Bogor yang paling menarik bagi investor industri yaitu Kecamatan Gunung Putri, Citeureup, Cibinong dan Cileungsi. Pemerintah Kabupaten Bogor sendiri berencana mengembangkan Kecamatan Cileungsi sebagai kawasan bisnis.

Tabel 2. Jumlah Penduduk Kecamatan Cileungsi

\begin{tabular}{|c|c|}
\hline TAHUN & $\begin{array}{c}\text { JUMAH } \\
\text { PENDUDUK }\end{array}$ \\
\hline 2014 & 302.522 \\
\hline 2015 & 316.873 \\
\hline 2016 & 331.605 \\
\hline 2017 & 347.414 \\
\hline
\end{tabular}

Sumber: BPS Kabupaten Bogor

Dari data resmi yang telah dipublikasi BPS Kabupaten Bogor, didapatkan pertumbuhan penduduk Kecamatan Cileungsi per tahun rata-rata 4,72\%, jauh lebih tinggi dari pertumbuhan penduduk Kabupaten Bogor pada periode yang sama yaitu rata-rata 2,34\% per tahun. Salah satu 
faktor penyebab tingginya pertumbuhan penduduk Kecamatan Cileungsi adalah munculnya banyak komplek perumahan di wilayah Kecamatan Cileungsi. Seiring dengan berkembangnya wilayah Kecamatan Cileungsi, sektor industri tumbuh dengan pesat. Berbagai usaha dalam skala kecil juga tumbuh. Usaha-usaha ini secara umum lebih sering disebut dengan istilah UMKM.

Dari penelitian yang dilakukan didapatkan bahwa profil ukuran usaha UMKM di Kecamatan Cileungsi dapat dilihat dari tabel 3. Kegiatan usaha pelaku UMKM Kecamatan Cileungsi 65,6\% dilakukan di rumah sendiri. Sebagian besar yaitu 94,6\% dilakukan sendiri atau dengan bantuan karyawan kurang dari lima orang.

Tabel 3. Profil Ukuran Usaha UMKM Kec. Cileungsi Menurut Omset

\begin{tabular}{|c|c|}
\hline UKURAN USAHA & PROSENTASE \\
\hline Usaha Mikro & $92,2 \%$ \\
\hline Usaha Kecil & $5,9 \%$ \\
\hline Usaha Menengah & $1,9 \%$ \\
\hline
\end{tabular}

Di Kecamatan Cileungsi terdapat 12 Desa. Tetapi sebagian besar UMKM Kecamatan Cileungsi, yaitu sebesar 65,7 persen berada di empat desa yaitu Cipenjo, Cileungsi Kidul, Limusnunggal dan Cipeucang. Tiga desa yaitu Cipenjo, Cileungsi Kidul dan Limusnunggal letaknya bersebelahan tersebut dan merupakan pusat Kecamatan Cileungsi. Kantor Kecamatan Cileungsi berada di Perumahan Metland Transyogi yang wilayahnya meliputi Desa Cipenjo, Cileungsi Kidul dan Limusnunggal. Pasar Cileungsi berada di Desa Cileungsi Kidul. Mall terbesar di Kecamatan Cileungsi juga berada di Perumahan Metland Transyogi. Sedangkan Desa Cipeucang cukup dekat dengan ketiga desa tersebut. Saat ini di empat desa tersebut lahan pertanian sudah sangat sempit. Sebagian besar sudah beralih menjadi perumahan.

Berdasarkan jenis usahanya, sebagian besar dari para pelaku UMKM di Kecamatan Cileungsi adalah usaha kuliner. Bidang-bidang lain jumlahnya hampir seimbang yaitu konveksi, kerajinan tangan dan perdagangan. Fakta ini sejalan dengan pertumbuhan usaha kuliner di beberapa kota di Indonesia yang semakin meningkat. Beberapa faktor yang menarik bagi pelaku UMKM untuk memilih usaha kuliner adalah kebutuhan terhadap makanan merupakan suatu kebutuhan utama manusia di segala usia (Sukri \& Arisandi, 2017). Kemudahan dalam pemasaran karena produk makanan memiliki permintaan yang tinggi sehingga perputaran uang yang sangat cepat (Adawiyah, 2014). Aktivitas manusia yang terus meningkat dan telah menyita waktu menuntut adanya penyedia layanan pemesanan dan pengiriman makanan (Pamungkas, 2016). Dan yang tidak kalah pentingnya adalah perkembangan internet yang pesat makin memudahkan pelanggan memesan makanan dari mana saja (Prapti NSS \& Rahoyo, 2019). 


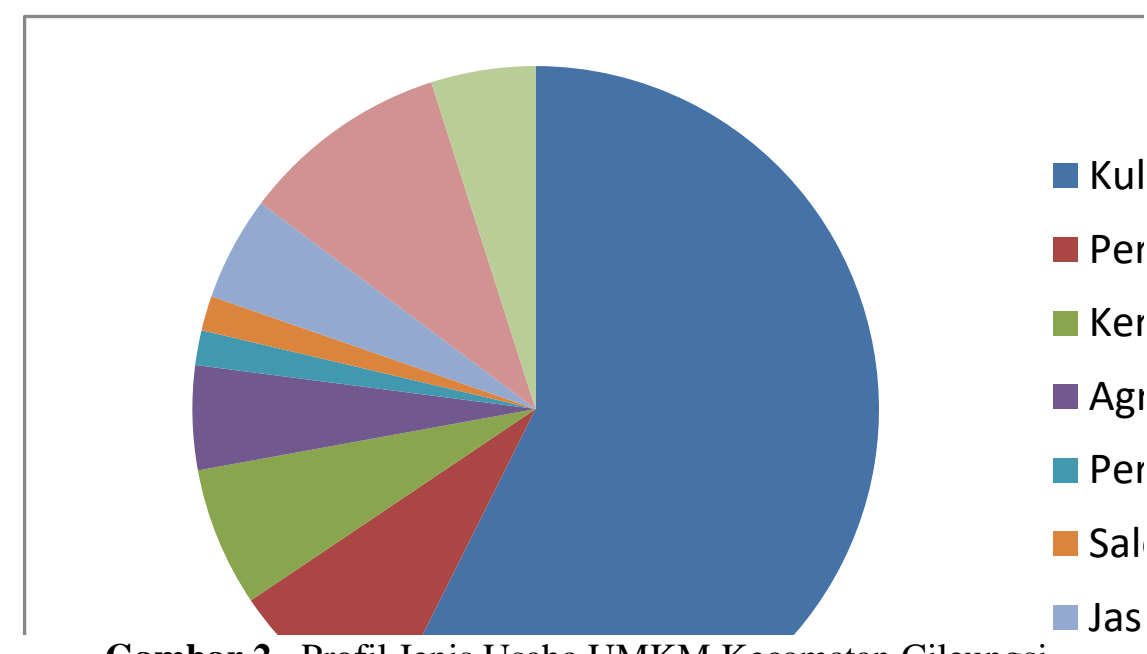

Gambar 2. Profil Jenis Usaha UMKM Kecamatan Cileungsi

Tetapi dengan segala daya tariknya, usaha kuliner tidak sedikit tantangannya. Dari beberapa penelitian yang dilakukan peneliti lain, salah satu yang menjadi tantangan adalah munculnya pelaku-pelaku usaha kuliner dari kelompok usaha besar dan nama-nama besar. Banyaknya bermunculan kuliner-kuliner franchise dari luar negeri maupun dalam negeri, misalnya Pizza Hut, KFC, Texas Chicken, CFC, JCo dan lain-lain (Besra, 2012). Usaha kuliner juga tanpa menghadapi kesulitan di dalam proses produksinya. Salah satu kesulitan terbesar di dalam melakukan proses proses produksi adalah ketersediaan alat dan teknologi yang kurang memadai. Fakta di lapangan menunjukkan mayoritas pelaku UMKM Kecamatan Cileungsi melakukan kegiatan usaha dengan cara perpaduan manual dan dengan teknologi sederhana. Hambatan terbesar dari UMKM Kecamatan Cileungsi untuk menjalankan usaha adalah dalam bidang pemasaran. Dari angket yang disebarkan, sebanyak $57,4 \%$ responden menjawab hambatan terbesar adalah pemasaran. Kondisi ini sesuai dengan penelitian yang telah dilakukan beberapa peneliti lain. Adawiyah yang menyampaikan bahwa salah satu hambatan dari UMKM di Kabupaten Banyumas adalah lemahnya jaringan pasar.

Tentu saja hal ini masalah penting yang perlu mendapatkan perhatian, karena pemasaran sangat besar pengaruhnya terhadap perkembangan usaha. Ditemukan beberapa UMKM yang sudah berdiri lebih dari 10 tahun tetapi total omsetnya masih di bawah 300 juta Rupiah per tahun. Pemasaran perlu mendapat perhatian serius oleh UMKM. Pada kondisi persaingan yang semakin ketat seperti saat ini, kemampuan untuk merebut pangsa pasar akan mempengaruhi kelangsungan hidup UMKM itu sendiri (Wibowo et al., 2015). Penguasaan ilmu pemasaran dari pelaku UMKM rata-rata masih kurang. Salah satu sebabnya adalah pendidikan rata-rata dari pelaku UMKM yang kurang. Sebanyak 52,5\% atau separuh lebih dari pemilik usaha UMKM di Kecamatan Cileungsi berpendidikan maksimal SMA atau sederajat. Tidak salah, ketika ditanyakan pembinaan apakah yang paling dibutuhkan, jawaban paling banyak dari responden adalah pembinaan atau pelatihan pemasaran. Salah satu wujud dari penguasaan ilmu pemasaran adalah rendahnya pemahaman pentingnya melakukan promosi. Sebanyak $70 \%$ pelaku UMKM Kecamatan Cileungsi tidak memiliki anggaran khusus untuk promosi. Ini adalah indikasi bahwa para pelaku UMKM melakukan kegiatan promosi tanpa rencana.

Hambatan kedua yang dihadapi para pelaku UMKM di Kecamatan Cileungsi adalah keuangan. Sebanyak $36,1 \%$ yang menjawab bahwa keuangan adalah hambatan terbesar. Ini bisa dimengerti karena hampir semua, yaitu 93,4\% pelaku UMKM menggunakan tabungan pribadi sebagai modal utama usaha. Fenomena ini tentu saja tidak hanya terjadi di Kecamatan Cileungsi. Beberapa penelitian terdahulu menyebutkan bahwa struktur modal UKM khususnya di Indonesia, hampir sebagian besar berdasar pada investasi pribadi (Perdagangan, 2013). 
Sementara itu Hasanah et al., (2020) mengungkapkan hal senada bahwa keterbatasan modal adalah salah satu hambatan UMKM di Purbalingga. Sebagian besar para pelaku UMKM Kecamatan Cileungsi tidak menggunakan dana bank untuk menjalankan usahanya. Alasan terbesar yang disampaikan responden adalah karena mereka tidak memiliki agunan. Alasan berikutnya adalah tidak memahami prosedur pengajuan pinjaman ke bank. Pemahaman para pelaku UMKM terhadap ilmu keuangan juga kurang. Terbukti sebagian besar mereka tidak melakukan pembukuan sesuai dengan kaidah akuntansi. Sebanyak 18\% tidak melakukan pembukuan keuangan sama sekali. Sedangkan $80,3 \%$ hanya melakukan pembukuan sederhana. Hanya $1,7 \%$ yang melakukan pembukuan dengan kaidah akuntansi. Hal ini selaras dengan beberapa penelitian sebelumnya bahwa sebagian besar pelaku UMKM kurang memiliki pemahaman mengenai keuangan dan akuntansi (Niode, 2009).

\section{PENUTUP}

Simpulan

Dari penelitian yang telah dilakukan didapatkan bahwa UMKM di Kecamatan Cileungsi mayoritas berukuran mikro. Bidang usaha yang paling menarik bagi pelaku UMKM di Kecamatan Cileungsi adalah usaha kuliner. Hambatan terbesar yang dihadapi oleh UMKM Kecamatan Cileungsi adalah pemasaran. Sebagian besar pelaku UMKM tidak memiliki ilmu pemasaran yang memadai untuk menghadapi persaingan yang sengit di dunia usaha. Hambatan kedua adalah dalam hal keuangan. Penguasaan ilmu tentang pembukuan keuangan para pelaku UMKM juga kurang mumpuni. Salah satu indikasinya adalah rendahnya penggunaan pembukuan keuangan dengan kaidah akuntansi.

\section{Saran}

Perlu dilakukan tindakan untuk membantu pelaku UMKM di Kecamatan Cileungsi di dalam menghadapi persaingan. Pemerintah Kabupaten Bogor dalam hal ini Kecamatan Cileungsi dan perguruan tinggi di Kecamatan Cileungsi bisa menggunakan data hasil penelitian untuk mengadakan langkah pembinaan berkesinambungan. Pembinaan yang sangat dibutuhkan oleh UMKM Kecamatan Cileungsi terutama berkaitan dengan pemasaran dan keuangan.

\section{REFERENSI}

Adawiyah, W. R. (2014). Faktor Penghambat Pertumbuhan Usaha Mikro Kecil Menengah (UMKM): Studi di Kabupaten Banyumas. JKMP (Jurnal Kebijakan Dan Manajemen Publik).

Bank Indonesia dan LPPI. (2015). Profil Bisnis Usaha Mikro, Kecil dan Menengah (UMKM). Bank Indonesia Dan LPPI.

Besra, E. (2012). Potensi Wisata Kuliner Dalam Mendukung Pariwisata Di Kota Padang. Jurnal Riset Akuntansi Dan Bisnis.

Hartono, H., \& Hartomo, D. D. (2016). FAKTOR-FAKTOR YANG MEMPENGARUHI PERKEMBANGAN UMKM DI SURAKARTA. Jurnal Bisnis Dan Manajemen. https://doi.org/10.20961/jbm.v14i1.2678

Hasanah, R. L., Kholifah, D. N., \& Alamsyah, D. P. (2020). Pengaruh modal , tingkat pendidikan dan teknologi terhadap pendapatan umkm di kabupaten purbalingga Effect of capital, education levels, and technology on msme income in purbalingga regency. Jurnal Akuntansi Dan Manajemen.

Jamkrindo. (2015). KRITERIA USAHA MIKRO, KECIL DAN MENENGAH MENURUT UU NO. 20 TAHUN 2008 TENTANG UMKM. BUMN.Go.Id.

Kemenperin. (2016). Kontribusi UMKM Naik. In Kompas Paper.

Lahamid, Q. (2018). Hambatan dan Upaya UMKM Kreatif Menjalankan Usaha Berbasis 
Syariah di Kota Pekanbaru. Sosial Budaya. https://doi.org/10.24014/sb.v15i1.4992

Lenora, B. (2008). Evaluasi program pemberdayaan usaha mikro kecil dan menengah (UMKM) "garda emas." Evaluasi Program Pemberdayaan Usaha Mikro Kecil Dan Menengah (UMKM) "Garda Emas."

Moh. Nazir. (2014). Metode Penelitian. Metode Penelitian. https://doi.org/978-979-450-173-5

Niode, I. Y. (2009). Sektor umkm di Indonesia: profil, masalah dan strategi pemberdayaan. Jurnal Kajian Ekonomi Dan Bisnis OIKOS-NOMOS.

Pamungkas, D. P. (2016). Sistem Informasi Kuliner di Indonesia ( Studi Kasus : Kulina . id ). Electronics, Informatics, and Vocational Education (ELINVO).

Perdagangan, K. (2013). Analisis Peran Lembaga Pembiayaan Dalam Pengembangan UMKM. Pusat Kebijakan Perdagangan Dalam Negeri.

Prapti NSS, R. L., \& Rahoyo, R. (2019). DAMPAK BISNIS KULINER MELALUI GO FOOD BAGI PERTUMBUHAN EKONOMI DI KOTA SEMARANG. Jurnal Dinamika Sosial Budaya. https://doi.org/10.26623/jdsb.v20i2.1243

Rahmadi, R., Soolany, C., \& Pratama, A. R. (2018). Penerapan Manajemen Strategi Pemasaran untuk Meningkatkan Daya Jual Produk UMKM Gula Merah di Kabupaten Cilacap. Jurnal Rekayasa Teknologi Industri Hijau.

Sabirin. (2016). Menilik Usaha Mikro Kecil Menengah (Umkm) Kesiapan Indonesia Menghadapi Masyarakat Ekonomi Asean (Mea). Kewirausahaan Dan Usaha Kecil Menengah.

Sarfiah, S., Atmaja, H., \& Verawati, D. (2019). UMKM Sebagai Pilar Membangun Ekonomi Bangsa. Jurnal REP (Riset Ekonomi Pembangunan). https://doi.org/10.31002/rep.v4i2.1952

Suci, Y. R., Tinggi, S., \& Ekonomi, I. (2017). Perkembangan UMKM (Usaha Mikro Kecil Menengah) di Indonesia. Jurnal Ilmiah Fakultasi Ekonomi.

Sukri, S., \& Arisandi, D. (2017). Analisis Strategi Pemasaran Dengan Media Sosial Produk Kuliner Usaha Kecil dan Menengah di Pekanbaru. Jurnal Buana Informatika. https://doi.org/10.24002/jbi.v8i4.1447

Wibowo, D. H., Arifin, Z., \& Sunarti. (2015). Analisis Strategi Pemasaran Untuk Meningkatkan Daya Saing UMKM. Jurnal Administrasi Bisnis. 